\title{
Aikuiskasvatus tukee elämänhallintaa
}

$\mathrm{O}$ ECD:n tulevaisuusohjelmassa pohdittiin tietotalouden ja -yhteiskunnan hallinnan kehitystä (21st century governance: Power in the global knwledge economy and society). Johtopäätöksenä oli, että nykyiset tavat johtaa julkista ja yksityistä sektoria ovat tulleet yhä tehottomammiksi. Hallinta edellyttää yhä useamman vaikuttajan osallistumista päätöksentekoon. Nykyisenkaltainen valtarakenteiden muuttumattomuus ja johtamisen autoritäärisyys kyseenalaistuvat perusteellisesti. Kysymys on myös muutoksista maailmankehityksen globaalissa hallinnassa.

Perinteinen ylhäältä alas suuntautuva ohjaus heikkenee. Innovatiivisten organisaatioiden toiminnan ohjauksessa luovutaan jäykistä auktoriteettirakenteista. Organisaation johtaminen muuttuu työtehtävien edellyttämällä tavalla. Osaamiseen perustuvissa toiminnoissa johtajuus siirtyy henkilöille, joilla on yksityiskohtaista tietoa ja osaamista sektorin kehityksestä, siinä haluttavista muutoksista ja kehitysmahdollisuuksista. Nykymuotoisella tulosten ja prosessien ennaltamäärittämiseen perustuvalla johtamisella ei ole enää käyttöä. Tavoitteiden asettaminen ja menettelytapojen valitseminen päätöksentekoon on toimintaan osallistuvien yksilöiden ja ryhmien innovatiivisuuden varassa. Muutosprosessien pitää perustua yhteisesti hyväksyttyihin tavoitteisiin ja yleisiin pelisääntöihin.

Tällainen liberaalinen suhtautuminen organisaatioiden kehitykseen ja luovuuden käyttöön edellyttää keskitetyn sääntelyn minimoimista. Tällä turvataan toimintojen monimuotoisuus ja sen myötä innovatiivisuus. Kollektiivisten tavoitteiden toteuttamiseen tarvittavien uusien hallintakeinojen käyttö edellyttää sitoutumista demokraattisiin arvoihin, ihmisoikeuksiin ja ihmisten yhdenvertaisten mahdollisuuksien ideologiaan. Tällöin hallituksille muodostuu kaksi haastetta. Niiden pitää turvata ihmisten kyvyt itseään koskevien päätösten tekemiseen ja toteuttamiseen. Osaaminen on siis perusedellytys uudistuksille. Lisäksi täytyy huolehtia, että yh- teisten pelisääntöjen ja laitosten toimintakentästä muodostuu joustava ihmisten yhteistyöhön perustuva päätöksentekoareena. Edellytetään siis hallinnan oppimista, mutta yhtä lailla oppimisen hallintaa. Tällöin oleellisen kysymyksen muodostaa, ovatko ihmiset siihen valmiita, eli halutaanko hallinnan muutosta toteuttaa kaikkien vaiko vain joidenkin ehdoilla. Kysymys on tärkeä, sillä tulevaisuudet eivät vain tule, vaan ne tehdään.

A ikuisväestön funktionaalisen lukutaidon tutkimus (Literacy in the information age) osoittaa, että lisääntyvä vastuun ottaminen voi olla joillekin vielä kaukainen ideaali. Lukutaidolla tutkimuksessa tarkoitettiin ihmisten kykyä ymmärtää ja käyttää kirjallisessa muodossa olevaa informaatiota osaamisensa lisäämiseen ja päämääriensä saavuttamiseen päivittäisessä kodin, työn ja vapaa-ajan toiminnassa. Lukutaitoa mitattiin proosan, dokumenttien ja numeeristen taitojen alueilla. Tutkimus osoitti, että huomattavalla osalla aikuisväestöä lukutaito on hyvin heikko tai vain auttava, eikä sillä vielä selvitä lisääntyvistä osaamisvaatimuksista. Hyvän lukutaidon tae on hyvä koulutustaso.

Yhden koulutusvuoden todettiin nostavan lukutaidon tasoa keskimäärin kymmenellä pisteellä. Myös ikä ja ammatti selittivät eroja. Korkeaa ammattitaitoa edellyttäviin toimihenkilöluokkiin kuuluvien lukutaito oli erittäin hyvä. Ikäryhmien vertailussa - silloinkin, kun tutkintoina mitattu koulutustaso oli sama - vanhemmat ikäluokat menestyivät nuoria heikommin. Selityksenä tähän lienee, että tutkintojen sisällöt olivat kehittyneet vastaamaan ajan vaatimuksia, mikä on normaalia. Taidot myös unohtuvat, jos niitä ei käytetä. Yhtä merkittävä tekijä oli vastaajan äidinkieli. Lukutaidon tasoon vaikutti myös työelämään ja aikuiskoulutukseen osallistuminen. Edellisiin selittäjiin verrattuna niiden merkitys lukutaidon tasoon osoittautui kuitenkin suhteellisesti vähäisemmäksi. Eroja selittävä tekijä oli myös vanhempien sosioekonominen tausta, 


\section{A J A N K O H T A I S T A}

mutta Pohjoismaissa sen vaikutus oli verraten pieni.

Suomalaisten lukutaito todettiin erittäin hyväksi. Silti ei ole syytä unohtaa, että osalla aikuisväestöämme on huomattavia vaikeuksia. Heikoimman lukutaidon omaavien luokkaan Suomessa kuuluu noin 11 prosenttia ja kahteen alimpaan luokkaan yhteensä noin 37 prosenttia aikuisväestöstä. Tämän väestönosan arvellaan helposti syrjäytyvän tietotalouden muutosvaatimusten alla. Näin erityisesti myös siksi, että osaajiakin on runsaasti saatavilla.

Tämä näkyy esimerkiksi Ranskassa ja Saksassa, joissa puuttuvaa osaajareserviä paikataan valikoivalla siirtolaispolitiikalla. Saksassa käynnistettiin kesäkuussa informaatioteknologian osaajien rekrytointi EU:n ulkopuolisista maista luvaten ensi vaiheessa 10000 tämän alan asiantuntijalle ja heidän perheilleen helpotettu pääsy Saksan työmarkkinoille (The Federal Republic of Germany's IT-specialists Temporary Relief Program). Luvattiin myös harkita kiintiön kaksinkertaistamista, sillä tätä palvelusektorin alaa luonnehditaan talouskasvun veturiksi.

Vaikka EU-maiden sisäinen työvoiman suuri liikkuvuus ei vielä olekaan todellisuutta, sekin toteutunee aikanaan ja alkaa puskea heikkoja taitoja omaavia yhä ahtaammalle. Voi olettaa, että meitäkin ensi vuoden alkupuolelta lähtien koskevan Schengenin sopimuksen psykologia ajaa tähän suuntaan. Voidaan siis kysyä, onko keskieurooppalaisen kaltainen aktiivinen siirtolaispolitiikka meidänkin tiemme, jos haluamme varmistaa tuotemerkkinä maailman jo viidenneksi arvokkaimmaksi listatun Nokian pysymisen Suomessa. Varmasti myös koulutusta pitää lisätä, mutta sen lääkkeet eivät pure tässä ja nyt, vaan vasta pidemmällä aikavälillä.

$\mathrm{S}^{\mathrm{k}}$ kenaariosta hallinnan uudistumisesta ei voia luopua, vaan siitä pitäisi pystyä tekemään totta. Yhteiskunnista tulee entistä monikulttuurisempia, jolloin on äärimmäisen tärkeätä pystyä turvaamaan eri väestöryhmien rauhanomainen rinnakkaiselo, mutta myös hyödyntämään moninaisuuden edut. Yhtenä keinona siinä on mo- nien tulevaisuuksien maailma, jossa otetaan vahvasti huomioon ihmisten ja heidän ryhmittymiensä näkemyksiä. Nyt ei ole näin, vaan ihmisten mielissä on monia epäilyjä, mikä näkyy mm. Seattlen WTO-neuvottelujen kariutumisessa, mutta myös uutta voimaa Euroopassa saaneessa ulkomaalaiskaunassa. Monet näistä luottamuksen puutteen osoituksista liittyvät tiedostettuun koulutuksen puutteeseen. Saksassa informaatioteknologian osaajien maahanmuuton helpottamista vastustettiin vaatimalla, että hallituksen pitäisi sen asemesta lisätä alan koulutusta.

$\mathrm{O}$ saamisen varmistaminen epäilemättä nousee myös Suomessa keskeiseksi poliittiseksi kysymykseksi aivan lähitulevaisuudessa, mihin vaikuttavat myös väestörakenteessa tapahtuvat muutokset. On kuitenkin samalla huolehdittava niistä, joiden selviytymisen edellytykset ovat heikoimmat. Hallinnan kehitystä pitäisi siis tarkastella myös elämänhallinnan kysymyksenä. Kesällä 2000 pidetyn OECD-ministerikokouksen päätelmissä pidettiin tärkeänä sosiaalisen koheesion aikaansaamista ja ylläpitämistä. Sillä voidaan tarkoittaa monia asioita, mutta keskeinen viesti lienee, että yhteiskuntien repeäminen eri kerrosten väkeen on este hyvinvoinnin säilyttämiselle ja yhteiskuntien turvallisuudelle. Eri mantereita edustavien yliopisto-opiskelijoiden tulevaisuusvisioita kuvaava tutkimusraportti tiivisti asian hyvin todeten, että tarvitaan yhteiskunnallista oikeudenmukaisuutta, hyvä koulutus ja työllisyyttä (Le Monde 25.-26.6.2000). Näiden tarpeellisuudesta varttuneemmatkin ovat varmasti yhtä mieltä. Perusturvallisuus pitää taata. Koulutuksen osuutena siinä on (laajassa mielessä) kulttuuriin integrointi. Aikuiskoulutuksen tehtävänä on auttaa uudistumaan ja hallitsemaan omaa elämää.

ReijoLaukkanen 